\title{
PENGARUH KEMAMPUAN PENGELOLAAN TATA RUANG PEMUKIMAN BANTARAN SUNGAI DAN GENDER TERHADAP NEW INVIRONMENTAL PARADIGM (NEP)
}

\author{
Basrawi $^{{ }^{*} \text {, Diana Vivanti }}{ }^{2}$, Yusriani Sapta Dewi ${ }^{3}$ \\ ${ }^{1}$ Kementrian Pemuda dan Olahraga RI, ${ }^{2}$ Universitas Negeri Jakarta, ${ }^{3}$ Universitas Setya Negara \\ Indonesia
}

Email: basrawi_besmart@yahoo.co.id

\begin{abstract}
The objective of this research is to find out the effect of Capabilities OF Resilience management of river (CRMR) and gender $(G)$ on new Environmental Paradigm (NEP). An expost facto method has been used by selecting 19 sample for each cell. Reliability of CRMR was .878, and New Environmental Paradigm (NEP) was .91. Data analyzed by two-way ANOVA. Research results revealed that there was new environmental paradigm significant difference between those people who have high capabilities of resilience management of river and low capabilities of resilience management of river. Moreover, there was significant interaction effect between Capabilities OF Resilience management of river (CRMR) and gender $(G)$ on New Environmental paradigm (NEP)
\end{abstract}

Keywords: Capabilities Of Resilience Management Of River And Gender Floating Against New Environmental paradigm (NEP) 


\section{PENDAHULUAN}

Indonesia merupakan salah satu Negara yang mempunyai penduduk terbesar ke empat di dunia, dengan penduduk yang begitu besar tentu diperlukan adanya pembangunan berkelanjutan (Sustainable Development) dan pemukiman yang layak untuk keberlangsungan hidup. Pembangunan yang dilakukan oleh pemerintah kota dan daerah dari pihak Negara maupun Swasta seringkali menimbulkan persoalan baik terhadap lingkungan maupun terhadap masyarakat. Masalahmasalah yang berpotensi terjadi pada pembangunan penggunaan lahan illegal menjadi pemukiman kumuh, padat dan tidak manusiawi dengan kualitas rendah/buruk, termasuk diantaranya penggunaan lahan bantaran sungai mulai hulu sampai hilir.

Problematika tersebut juga terjadi di DKI Jakarta sangat komplek terkait dengan tata ruang, salah satunya adalah pemukiman yang terdapat pada Bantaran Sungai Ciliwung. Kasus yang terjadi pada Kampung Pulo, lahan permukiman di Bantaran Sungai tersebut terjadi sengketa antara warga setempat dengan pemerintah DKI Jakarta sehingga banyak warga yang menolak atas eksekusi lahan tersebut walaupun pada akhirnya relokasi ke tempat lain yang sudah disediakan oleh pemerintah DKI Jakarta. Tidak hanya itu masih banyak kasus serupa yang terjadi, hal ini merupakan lemahnya kebijakan pemerintah DKI Jakarta dalam menerapkan undang-undang tentang tata ruang pemukiman Bantaran Sungai.

Pemukiman di Bantaran Sungai Ciliwung merupakan masalah yang sangat serius untuk diselesaikan secara lebih seksama mengingat keberadaannya telah menjadi suatu dilema tersendiri. Satu sisi keberadaan pemukiman ini berakar pada motif sosial, ekonomi dan budaya sehingga mendorong manusia yang berada di tepi sungai tersebut untuk memanfaatkan sebesar-besarnya potensi yang ada di Bantaran Sungai tersebut. Pada sisi lain wilayah tepi sungai merupakan suatu kawasan yang perlu mendapat perlindungan dari berbagai faktor yang dapat merusak ekosistemnya. Disisi lain, perkembangan kebutuhan pemukiman akan diikuti dengan peningkatan kebutuhan lahan.

Lahan di perkotaan, seperti di DKI Jakarta sangatlah terbatas dan cenderung statis pertumbuhannya. Keterbatasan lahan tersebut mendorong meningkatnya harga lahan secara cepat. Tingginya kebutuhan pemukiman, 
kompleksitas masalah pemukiman yang antara lain ditimbulkan akibat rendahnya tingkat pendidikan serta tingkat sosial ekonomi, mengakibatkan kualitas hunian maupun lingkungan menjadi sangat kumuh, di samping umumnya memiliki kerawanan terhadap wabah penyakit, tindak kriminal, bencana kebakaran serta kerawanan sosial lainnya lemahnya perekonomian sebagian besar masyarakat perkotaan dan keterbatasan lahan menjadi faktor penyebab semakin berkembangnya pemukiman ilegal.

Salah satu permasalahan lingkungan di wilayah Jakarta adalah penyusutan ruang terbuka hijau yang telah direncanakan akibat konflik penggunaan lahan. Hal ini mengakibatkan munculnya New environmental paradigm (NEP) memanfaatkan lingkungan sekitar agar tidak menimbulkan kerusakan lingkungan dengan memanfaatkan lahan sekitar sungai sebanyak banyaknya untuk kepentingan masyarakat setempat agar terhindar dari banjir sehingga tidak terjadi kerusakan sungai yang akan berpengaruh pada terjadinya pengikisan tanah pada saat hujan (soil erosion). Untuk itu masyarakat harus memiliki New environmental paradigm (NEP) sebab paradigma dapat mengubah masyarakat itu sendiri. Seperti hasil penelitian Ron Sookram yang menyatakan New environmental paradigm (NEP) dapat diterapkan untuk menentukkan sikap lingkungan dari manajer, tetapi paradigma sosisal juga dominan untuk menjadikan pembangunan yang berkelanjutan.

Pemahaman paradigma sebagai salah satu langkah untuk mengetahui makna dari paradigma. Denzin \& Lincoln(2000:105-107),

mendefinisikan paradigma sebagai: "Basic belief system or worldview that guides the investigator, not only in choices of method but in ontologically and epistomologically fundamental ways".

Pengertian tersebut mengandung makna paradigma adalah sistem keyakinan dasar atau cara memandang dunia yang membimbing peneliti tidak hanya dalam memilih metoda tetapi juga caracara fundamental yang bersifat ontologis dan epistomologis. Selanjutnya dinyatakan pula bahwa, "Paradigm as Basic Belief Systems Based on Ontological, Epistomological, and Methodological Assumptions". Paradigma merupakan sistem keyakinan dasar berdasarkan asumsi ontologis, epistomologis, dan metodologi. Begitu 
pula Denzin \& Lincoln menyatakan: “ $A$ paradigm may be viewed as a set of basic beliefs (or metaphysics) that deals with ultimates or first principle". Suatu paradigma dapat dipandang sebagai seperangkat kepercayaan dasar (atau yang berada di balik fisik yaitu metafisik) yang bersifat pokok atau prinsip utama. Ada paradigma yang digunakan sebagai suatu model untuk mempelajari fungsi-fungsi, teori-teori, dan memecahkan masalah yang kompleks dan ada pula yang digunakan untuk mendefinisikan suatu konsep. Sedangkan pengertian paradigma menurut Patton di dalam Guba (1990:80) menyatakan: a world view, a general perspective, a way of breaking down the complexity of the real world ... paradigms are deeply embedded in the socialization of adherents and practitioners telling them what is important, what is legitimate, what is reasonable. Paradigms are normative; they tell the practitioner what to do without the necessity of long existential or epistemological considerations. Paradigma yang normatif, memberitahu praktisi apa yang harus dilakukan tanpa perlu pertimbangan eksistensial atau epistemologis yang panjang.

Pada awal tahun 1980, di tiga negara melakukan studi lingkungan yaitu
Inggris, Jerman, dan Amerika Serikat yang membandingkan keyakinan dan nilai-nilai lingkungan, tujuannya adalah untuk mempelajari keyakinan nilai-nilai dari dominant social paradigm (DSP) dan new environmental paradigm (NEP). Studi tersebut memberikan bukti kuat bahwa new environmental paradigm (NEP) berbeda secara signifikan dari dominant social paradigm (DSP) dalam Sheldon (1993:23). New environmental paradigm (NEP) dikembangkan oleh Riley E. Dunlap dan Kent D. Van Liere pada tahun 1978 dan mengalami revisi pada tahun 2000. Revisi dilakukan karena begitu kompleksnya permasalahan yang ditimbulkan dari tahun ke tahun. Sebab masalah utama di tahun 1978 adalah polusi udara, air, kurang menghargai alam dan konservasi energi. Beberapa dekade kemudian masalah yang ditimbulkan adalah kerusakan ozone, pembabatan hutan, berkurangnya keanekaragaman hayati dan perubahan iklim global. Skala NEP tersebut menyangkut realitas tentang adanya batas pertumbuhan (the reality of limits to growth), anti-antroposentrisme (antianthropocentrisme), kerapuhan pada keseimbangan alam (the fragility of nature's balance), penolakan pada 
pembebasan

(rejection

of

exemptionalim) dan kemungkinan

adanya krisis ekologi (the possibility of ecocrisis) dalam Dunlap Jurnal.

Berikut ini Lester W. Milbrath dalam Kamieniecki, menyatakan sebuah masyarakat yang menganut pada nilainilai dan keyakinan NEP akan sangat berbeda dari masyarakat modern yang menganut DSP.

Tabel 1.

Perbedaan Fundamental Nilai dan Kepercayaan antara Dominant Social Paradigm dan New Environmental Paradigm.

\begin{tabular}{|l|l|}
\hline $\begin{array}{l}\text { Dominant Social } \\
\text { Paradigm (DSP) }\end{array}$ & $\begin{array}{l}\text { New } \\
\text { Environmental } \\
\text { Paradigm (NEP) }\end{array}$ \\
\hline $\begin{array}{l}\text { Prioritas pada } \\
\text { pertumbuhan } \\
\text { ekonomi dan } \\
\text { pembangunan, pada } \\
\text { fokus pada } \\
\text { kesejahteraan } \\
\text { jangka pendek. } \\
\text { kelangsungan } \\
\text { hidup ekosistem, } \\
\text { fokus pada } \\
\text { keberlanjutan } \\
\text { jangka panjang. }\end{array}$ \\
$\begin{array}{l}\text { Kelanjutan } \\
\text { pertumbuhan } \\
\text { ekonomi } \\
\text { membenarkan } \\
\text { bahaya gangguan } \\
\text { sistem } \\
\text { biogeokimia }\end{array}$ & $\begin{array}{l}\text { Gangguan sistem } \\
\text { biogeo kimia } \\
\text { jarang, jika } \\
\text { pernah, } \\
\text { dibenarkan. }\end{array}$ \\
\hline $\begin{array}{l}\text { Menerima resiko } \\
\text { untuk } \\
\text { memaksimalkan } \\
\text { kekayaan }\end{array}$ & $\begin{array}{l}\text { Menghindari } \\
\text { risiko terhadap } \\
\text { ekosistem dan } \\
\text { semua } \\
\text { kesejahteraan atas } \\
\text { sosial }\end{array}$ \\
\hline $\begin{array}{l}\text { Ketergantungan } \\
\text { pada pasar untuk } \\
\text { memacu }\end{array}$ & $\begin{array}{l}\text { Ketergantungan } \\
\text { pada pandangan } \\
\text { ke depan dan }\end{array}$ \\
\hline
\end{tabular}

\begin{tabular}{|c|c|}
\hline $\begin{array}{l}\text { Dominant Social } \\
\text { Paradigm (DSP) }\end{array}$ & $\begin{array}{l}\text { New } \\
\text { Environmental } \\
\text { Paradigm (NEP) }\end{array}$ \\
\hline $\begin{array}{l}\text { pertumbuhan dan } \\
\text { memastikan masa } \\
\text { depan yang cerah }\end{array}$ & $\begin{array}{l}\text { perencanaan } \\
\text { untuk } \\
\text { memastikan masa } \\
\text { depan yang cerah }\end{array}$ \\
\hline $\begin{array}{l}\text { anan pada } \\
\text { san langsung } \\
\text { entasi } \\
\text { al }\end{array}$ & $\begin{array}{l}\text { Penekanan pada } \\
\text { struktur } \\
\text { horisontal dan } \\
\text { desentralisasi }\end{array}$ \\
\hline $\begin{array}{lr}\text { Penekanan } & \text { pada } \\
\text { hirarki } & \text { dan } \\
\text { terpusat } & \\
\end{array}$ & $\begin{array}{l}\text { Penekanan pada } \\
\text { kesederhanaan } \\
\text { dan desentralisasi }\end{array}$ \\
\hline $\begin{array}{l}\text { Pengambilan } \\
\text { keputusan dan } \\
\text { tanggung jawab } \\
\text { terpusat }\end{array}$ & $\begin{array}{ll}\text { Lebih } & \text { besar } \\
\text { tanggung jawab } \\
\text { pribadi dan lokal }\end{array}$ \\
\hline $\begin{array}{l}\text { Keyakinan yang } \\
\text { sangat besar dalam } \\
\text { ilmu pengetahuan } \\
\text { dan teknologi }\end{array}$ & $\begin{array}{lr}\text { Skeptisisme } & \text { dan } \\
\text { evaluasi kritis } \\
\text { terhadap ilmu } \\
\text { pengetahuan dan } \\
\text { teknologi }\end{array}$ \\
\hline $\begin{array}{l}\text { Ketergantungan } \\
\text { pada mekanistik } \\
\text { sederhana / efek } \\
\text { pemikiran keahlian } \\
\text { sempit }\end{array}$ & $\begin{array}{l}\text { Pengakuan } \\
\text { kebutuhan } \\
\text { holistik / berpikin } \\
\text { integratif }\end{array}$ \\
\hline $\begin{array}{l}\text { Penekanan pada } \\
\text { persaingan, } \\
\text { dominasi patriarki }\end{array}$ & $\begin{array}{l}\text { Penekanan pada } \\
\text { kerja sama, } \\
\text { kemitraan, } \\
\text { egalitarianisme }\end{array}$ \\
\hline $\begin{array}{l}\text { Kekerasan yang } \\
\text { dibutuhkan untuk } \\
\text { Mempertahankan } \\
\text { dominasi dan } \\
\text { tatanan sosial }\end{array}$ & \begin{tabular}{lr}
\multicolumn{2}{l}{ Keengganan } \\
untuk kekerasan \\
dilihat sebagai \\
merusak tatanan \\
sosial
\end{tabular} \\
\hline $\begin{array}{l}\text { Sifat kepentingan } \\
\text { manusia }\end{array}$ & $\begin{array}{l}\text { Menempatkan } \\
\text { manusia dalam } \\
\text { konteks } \\
\text { ecosystemic }\end{array}$ \\
\hline $\begin{array}{l}\text { Menekankan } \\
\text { kebebasan asalkan } \\
\text { melayani prioritas } \\
\text { ekonomi }\end{array}$ & $\begin{array}{l}\text { Menekankan } \\
\text { kebebasan } \\
\text { asalkan melayani } \\
\text { imperatif ekologi } \\
\text { dan sosial }\end{array}$ \\
\hline
\end{tabular}


Pada Tabel 1 mengambarkan manusia Dominant Social Paradigm (DSP) mengasumsikan bahwa suatu tempat perbelanjaan atau pasar merupakan mekanisme terbaik untuk memaksimalkan pertumbuhan ekonomi dan kesejahteraan manusia, kemudian mereka menolak sebagian besar perencanaan, terutama oleh pemerintah. Kelompok ini pro-eksploitasi sumber daya alam, materialistis, mengagungagungkan ilmu dan teknologi. Sebaliknya, manusia yang menganut New Environmental Paradigm (NEP) memihak kepada kelestarian lingkungan. Manusia dalam kelompok ini mencintai alam, percaya pada batasbatas pertumbuhan, sadar bahwa manusia adalah bagian dari ekosistem, sadar bahwa terdapat saling ketergantungan dan keterikatan antara manusia dan alam.

Dominant social paradigm pada dasarnya dengan penilaian sebaliknya (bertentangan dengan Paradigma Baru Ekologi): bahwa manusia diciptakan untuk memerintah atas bumi, dan penggunaan sumber daya alam yang berlebihan yang dapat tergantikan dan ditemukan (Dunlap dan Van Liere 1978) dalam penelitian (Emily 2009:154). Artinya bahwa manusia diciptakan untuk menggunakan sumber daya alam yang sebanyak-banyaknya.

Menurut Örjan Wiidegren dijelaskan bahwa skala New Environmental Paradigm adalah digunakan dengan menggunakan indikator kesadaran dari akibat, keyakinan kecendurangan untuk mempunyai perasaan bersalah, jika merusak lingkungan, adalah menggunakan indikator dari sebuah nilai individu.

Prinsip kesetaraan gender dalam pengelolaan daerah aliran sungai menuntut tersedianya data-data yang bisa menunjukkan bahwa terjadi ketimpangan baik pada akses, partisipasi, kontrol dan manfaat dalam pelaksanaan pengelolaan sumberdaya air bagi laki-laki dan perempuan. Data tersebut akan memberi legitimasi kuat terhadap sasaran program pembangunan yang akan dilaksanakan. Sehingga kemampuan dari setiap individu sangat berperan untuk mengelola bantaran sungai. Separti dalam penelitian Hodis D Denis mengtakan bahwa sebagian orang mendukung New environmental paradigm (NEP), degan optimisme teknologi dan kepercayaan terhadap sumber daya tak terbatas masih sangat mempengaruhi pemikiran saat ini (2014:4). Robbins dan Judge (2012:53), 
mengatakan, “ability An individual's capacity to perform the various tasks in a job", kemampuan adalah kapasitas seseorang individu untuk melakukan berbagai tugas dalam suatu pekerjaan. Kemampuan adalah sebuah penilaian terkini atas apa yang dapat dilakukan seseorang

Untuk itu penyediaan data ataupun indikasi untuk mengarahkan cara melihat data berbasis gender pada pengelolaan sumberdaya air yang saat ini masih sangat minim, oleh karena itu perlu kiranya dibuat profil gender sebagai upaya membantu dalam melihat data berbasis gender tersebut. Karena peranan gender merupakan salah satu penentu keberlanjutan lingkungan seperti yang dikatakan dalam The Environment and Gender Index (EGI) (2013:15) Gender is a distinguishing factor in determining human relationships with the environment. Women and men have difference responsibilities, knowledge, and needs in relation to natural resources.

Berdasarkan latar belakang di atas maka penelitian akan difokuskan terhadap tata ruang pemukiman yang ada di Bantaran Sungai Manggarai yaitu meliputi; (1) aspek New environmental paradigm (NEP), (2) aspek pemberdayaan gender.
Seharusnya setiap orang baik laki-laki maupun perempuan yang tinggal di bantaran sungai Manggarai berkewajiban memelihara kelestarikan fungsi sungai serta mengendalikan pencemaran dan kerusakan sungai.

\section{METODOLOGI}

Penelitian yang digunakan pada peneitian ini adalah ex-post facto, desain penelitian ex-post facto adalah jenis desain yang mirip dengan studi eksperemental dalam arti bahwa hal itu juga berusaha untuk membangun sebab-akibat tetapi berbeda dari itu dalam peneliti biasanya tidak memiliki kontrol atas variabel kepentingan dan tidak dapat memanipulasi atas variabel tersebut Madu \& Akobi (2014:27). Kannan dan Rajamohan (2014:27) Karakteristik utama dari "ex-post facto," adalah bahwa metode penelitian tidak memiliki kontrol atas variabel yang diteliti dan hanya bisa melaporkan apa yang telah terjadi. "metode ex-post facto," juga digunakan untuk studi deskriptif dengan cara peneliti berusaha untuk mengukur variabel. Adapun populasi target dalam penelitian ini yaitu seluruh warga yang berdomisili di sekitar bantaran sungai Mangarai. Populasi terjangkau dalam penelitian ini adalah seluruh warga yang 
berjumlah 200 orang. Dari jumlah populasi terjangkau di atas, maka dilakukan penarikan sampel dengan teknik sampling purposive yaitu teknik penentuan sampel dengan pertimbangan tertentu. Teknik ini bisa diartikan sebagai suatu proses pengambilan sampel dengan menentukan terlebih dahulu jumlah sampel yang hendak diambil, kemudian pemilihan sampel dilakukan berdasarkan tujuan-tujuan yang diinginkan peneliti, dengan ketentuan tidak menyimpang dari ciri-ciri sampel yang ditetapkan.

Jumlah sampel ditentukan sebanyak 200 orang laki - laki dan perempuan yang dinilai mewakili seluruh populasi yang ada, dengan jumlah laki - laki sebanyak 19 orang, dan perempuan sebanyak 19 orang. Peneliti memberikan Instrumen yang berkaitan dengan kemampuan pengelolaan tata ruang pemukiman bantaran sungai. Hasilnya berupa skor disusun dalam urutan rangking tertinggi hingga yang terendah. Selanjutnya ditetapkan dua kelompok yakni atas dan bawah berdasarkan ranking skornya.

Pada tahap selanjutnya, penarikan sampel untuk menentukan kelompok dilakukan dengan ketentuan kelompok laki-laki yang memiliki kemampuan pengelolaan tata ruang pemukiman bantaran sungai dengan proporsi $27 \%$ sebagai kelompok atas (high level) dan proporsi $27 \%$ sampel dengan kelompok perempuan yang memiliki kemampuan pengelolaan tata ruang pemukiman bantaran sungai sebagai kelompok bawah (low level).

Berdasarkan proporsi tersebut kemudian warga diberikan tes dominant new environmental paradigm. Dengan proporsi 27\%, diperoleh sebanyak 19 orang yang ditetapkan sebagai kelompok laki-laki yang memiliki kemampuan pengelolaan tata ruang pemukiman bantaran sungai $\left(\mathrm{A}_{1} \mathrm{~B}_{1}\right)$, dan 19 orang yang ditetapkan sebagai kelompok laki-laki yang memiliki kemampuan pengelolaan tata ruang pemukiman bantaran sungai rendah $\left(\mathrm{A}_{2} \mathrm{~B}_{1}\right)$, demikian juga 19 orang yang ditetapkan sebagai kelompok perempuan yang memiliki kemampuan pengelolaan tata ruang pemukiman bantaran sungai tinggi $\left(A_{1} B_{2}\right)$, dan 19 orang yang ditetapkan sebagai kelompok perempuan yang memiliki kemampuan pengelolaan tata ruang pemukiman bantaran sungai rendah $\left(\mathrm{A}_{2} \mathrm{~B}_{2}\right)$. 


\section{HASIL DAN PEMBAHASAN}

Data deskriptif penelitian ini diperoleh dengan menggunakan teknik pengumpulan data non tes berupa instrumen. Data hasil penelitian yang dideskripsikan meliputi data variabel bebas yakni kemampuan pengelolaan tata ruang permukiman bantaran sungai (X1) dan gender (X2) serta variabel terikat yakni new environmental paradigm $(\mathrm{Y})$.

Berdasarkan permasalahan dalam penelitian ini, maka deskripsi data pada penelitian ini adalah data tentang new environmental paradigm bagi masyarakat. Kemampuan pengelolaan tata ruang permukiman bantaran sungai tinggi (A1).

Hasil data penelitian menunjukkan bahwa skor perilaku new environmental paradigm bagi masyarakat dengan kemampuan pengelolaan tata ruang permukiman bantaran sungai tinggi dengan responden sebanyak 36 orang maka diperoleh nilai mean sebesar 66; median sebesar 66; modus sebesar 69; varians sebesar 69,078 dan standar deviasi sebesar 4,71.

Dapat diketahui bahwa kelompok kemampuan pengelolan tata ruang bantaran sungai tinggi memiliki skor new environmental paradigm yang cukup tinggi dengan mayoritas sebanyak 10 orang memiliki nilai skor dari 66 - $68 \quad(26,32 \%)$ dan yang kelompok yang paling sedikit (berjumlah satu orang) adalah kelompok data dengan skor 57 - 69.

Kemampuan pengelolaan tata ruang permukiman bantaran sungai rendah (A2). Hasil data penelitian menunjukan bahwa skor new environmental paradigm bagi masyarakat dengan kemampuan pengelolaan tata ruang permukiman bantaran sungai rendah dengan responden sebanyak 36 orang maka diperoleh nilai mean sebesar 62; median sebesar 63; modus sebesar 66 dan standar deviasi sebesar 4,66. Dapat diketahui bahwa skor tertinggi new environmental paradigm pada kemampuan pengelolaan tata ruang permukiman bantaran sungai rendah adalah 63-65 $(26,31)$ dan 69-71 $(7,89)$ lebih rendah dibandingkan kelompok kemampuan pengelolaan tata ruang permukiman bantaran sungai tinggi, dan yang berjumlah paling sedikit adalah kelompok data dengan skor tinggi 132 - $138(0 \%)$.

Kelompok masyarakat laki-laki yang memiliki kemampuan pengelolaan tata ruang permukiman bantaran sungai tinggi (A1B1), Hasil data penelitian menunjukan bahwa skor new 
environmental paradigm pada Masyarakat Laki-laki dengan Kemampuan Pengelolaan Tata Ruang bantaran sungai Tinggi dengan responden sebanyak 19 orang diperoleh nilai mean sebesar 68; median sebesar 68; modus sebesar 74; dan standar deviasi sebesar 4,16. Dapat diketahui bahwa rentang kelas yang dimiliki oleh kelompok laki-laki dengan kemampuan pengelolaan tata ruang bantaran sungai tinggi mempunyai skor tinggi dari skor $67-69$.

Kelompok masyarakat laki-laki yang memiliki kemampuan pengelolaan tata ruang permukiman bantaran sungai rendah (A2B1), Hasil data penelitian menunjukan bahwa skor new environmental paradigm pada masyarakat laki-laki dengan kemampuan pengelolaan tata ruang bantaran sungai rendah dengan responden sebanyak 19 orang maka diperoleh nilai mean sebesar 62; median sebesar 64; modus sebesar 66; dan standar deviasi sebesar 4,64. Dapat diketahui bahwa rentang skor berada pada skor 54 sampai 73.

Kelompok masyarakat perempuan yang memiliki kemampuan pengelolaan tata ruang permukiman bantaran sungai tinggi (A1B2), Hasil data penelitian menunjukan bahwa skor new environmental paradigm bagi masyarakat perempuan dengan kemampuan pengeolaan tata ruang bantaran sungai tinggi dengan responden sebanyak 19 orang maka diperoleh nilai mean sebesar 63; median sebesar 65; modus sebesar 66; dan standar deviasi sebesar 3,97. Dapat diketahui bahwa rentang skor pada kelompok perempuan dengan kemampuan pengelolaan tata ruang bantaran sungai tinggi memiliki skor 66 - 68, lebih rendah dibandingkan kelompok laki-laki dengan kemampuan pengelolaan tata ruang bantaran sungai tinggi.

Kelompok masyarakat perempuan yang memiliki kemampuan pengelolaan tata ruang permukiman bantaran sungai rendah (A2B2). Hasil data penelitian menunjukan bahwa skor new environmental paradigm pada Masyarakat Perempuan dengan Kemampuan Pengelolaan Tata Ruang bantaran sungai Rendah dengan responden sebanyak 19 orang maka diperoleh nilai mean sebesar 62 ; median sebesar 63; modus sebesar 63; dan standar deviasi sebesar 4,80. Dapat diketahui bahwa rentang skor kelompok pria dengan kemampuan pengelolaan tata ruang bantaran sungai rendah memiliki skor 62 sampai 65 , 
yang sama dengan kelompok laki-laki dengan kemampuan pengelolaan tata ruang bantaran sungai rendah.

Dalam penelitian ini, pengujian persyaratan analisis parametrik yang dilakukan adalah uji normalitas dan uji homogenitas.

Uji normalitas merupakan upaya mengetahui apakah sebaran dari skor masing-masing variabel, baik variabel bebas maupun variabel terikat berdistribusi normal atau mendekati normal atau tidak normal. Uji normalitas distribusi data dilakukan dengan uji Liliefors terhadap 4 kelompok data yaitu :

Data new environmental paradigm pada masyarakat laki-laki dengan kemampuan pengelolaan tata ruang permukiman bantaran sungai tinggi (A1B1)

Pada pengujian normalitas distribusi data new environmental paradigm pada masyarakat laki-laki dengan kemampuan pengelolaan tata ruang permukiman bantaran sungai tinggi pada taraf kepercayaan 0,05 menunjukan nilai $\mathrm{L}_{\text {hitung }}=0,225<\mathrm{L}_{\text {tabel }}$ $=0,229$. Maka dapat disimpulkan bahwa data new environmental paradigm pada masyarakat laki-laki dengan kemampuan pengelolaan tata ruang permukiman bantaran sungai tinggi berdistribusi normal karena $\mathrm{L}_{\text {hitung }}<\mathrm{L}_{\text {tabel }}$.

Data new environmental paradigm pada masyarakat laki-laki dengan kemampuan pengelolaan tata ruang permukiman bantaran sungai rendah (A2B1)

Pada pengujian normalitas distribusi new environmental paradigm pada masyarakat laki-laki dengan kemampuan pengelolaan tata ruang permukiman bantaran sungai rendah pada taraf kepercayaan 0,05 menunjukan nilai $\mathrm{L}_{\text {hitung }}=0,267>\mathrm{L}_{\text {tabel }}$ $=0,183$ Maka dapat disimpulkan bahwa data new environmental paradigm pada masyarakat laki-laki dengan kemampuan pengelolaan tata ruang permukiman bantaran sungai rendah berdistribusi normal karena $\mathrm{L}_{\text {hitung }}<\mathrm{L}_{\text {tabel }}$.

Data new environmental paradigm pada masyarakat wanita dengan kemampuan pengelolaan tata ruang permukiman bantaran sungai tinggi (A1B2)

Pada pengujian normalitas distribusi data new environmental paradigm pada masyarakat wanita dengan kemampuan pengelolaan tata ruang permukiman bantaran sungai tinggi pada taraf kepercayaan 0,05 menunjukan nilai $\mathrm{L}_{\text {hitung }}=0,215<\mathrm{L}_{\text {tabel }}=0,308$. Maka 
dapat disimpulkan bahwa data new environmental paradigm pada masyarakat wanita dengan kemampuan pengelolaan tata ruang permukiman bantaran sungai tinggi berdistribusi normal karena $\mathrm{L}_{\text {hitung }}<\mathrm{L}_{\text {tabel. }}$.

Data new environmental paradigm pada masyarakat wanita dengan kemampuan pengelolaan tata ruang permukiman bantaran sungai rendah (A2B2)

Pada pengujian normalitas distribusi data new environmental paradigm pada masyarakat wanita dengan kemampuan pengelolaan tata ruang permukiman bantaran sungai rendah pada taraf kepercayaan 0,05 menunjukan nilai $\mathrm{L}_{\text {hitung }}=0,358>\mathrm{L}_{\text {tabel }}=0,308$. Maka dapat disimpulkan bahwa data new environmental paradigm pada masyarakat wanita dengan kemampuan pengelolaan tata ruang permukiman bantaran sungai rendah berdistribusi normal karena $\mathrm{L}_{\text {hitung }}<\mathrm{L}_{\text {tabel }}$.

Pengujian normalitas data di atas bahwa distribusi empat kelompok data tersebut terutama data yang secara langsung dianalisis dengan analisis variansi dua jalur memenuhi asumsi normal dengan kriteria pengujian apabila $\mathrm{L}_{\text {hitung }}<\mathrm{L}_{\text {tabel }}$ data berasal dari populasi yang berdistribusi normal.Apabila hasil-hasil keseluruhan uji normalitas data tersebut di atas dinyatakan dalam bentuk tabel maka diperoleh data sebagai berikut:

Tabel 2.

Rekapitulasi hasil uji normalitas data

\begin{tabular}{|l|l|l|l|}
\hline $\begin{array}{l}\text { Kelomp } \\
\text { ok } \\
\text { Sampel }\end{array}$ & $\begin{array}{l}\text { L(hitun } \\
\text { g) }\end{array}$ & $\begin{array}{l}\text { L } \\
\text { (tabe } \\
\text { l) }\end{array}$ & $\begin{array}{l}\text { Kesimpul } \\
\text { an }\end{array}$ \\
\cline { 1 - 3 } $\mathrm{A}_{1}$ & 0,229 & 0,05 & Berdistrib \\
\cline { 1 - 3 } $\mathrm{A}_{2}$ & 0,284 & 0,05 & usi \\
\cline { 1 - 3 } $\mathrm{B}_{1}$ & 0,183 & 0,05 & Normal \\
\cline { 1 - 3 } $\mathrm{B}_{2}$ & 0,308 & 0,05 & \\
\hline
\end{tabular}

\begin{tabular}{|l|l|l|l|}
\hline $\begin{array}{l}\text { Kelomp } \\
\text { ok } \\
\text { Sampel }\end{array}$ & $\begin{array}{l}\text { L } \\
\text { (hitun } \\
\text { g) }\end{array}$ & $\begin{array}{l}\text { L } \\
\text { (tabe } \\
\text { 1) }\end{array}$ & $\begin{array}{l}\text { Kesimpul } \\
\text { an }\end{array}$ \\
\hline $\mathrm{A}_{1} \mathrm{~B}_{1}$ & 0,225 & 0,05 & Berdistrib \\
\cline { 1 - 3 } $\mathrm{A}_{1} \mathrm{~B}_{2}$ & 0,215 & 0,05 & usi \\
\cline { 1 - 2 } $\mathrm{A}_{2} \mathrm{~B}_{1}$ & 0,267 & 0,05 & Normal \\
\cline { 1 - 2 } $\mathrm{A}_{2} \mathrm{~B}_{2}$ & 0,358 & 0,05 & \\
\hline
\end{tabular}

Uji homogenitas diperlukan untuk uji kesamaan atau perbedaan varians atau penyebaran dari beberapa kelompok data. Jika penyebarannnya sama maka artinya data bersifat homogen. Uji ini dilakukan dengan uji Bartlett yang kelompok datanya berdistribusi normal. Uji homogenitas ini dilakukan dengan tujuan mengetahui tingkat ragam varians yang menjadi salah satu syarat dalam melakukan uji $\mathrm{T}$ yang akan dilakukan untuk mengethui seberapa jauh pengaruh satu variabel bebas secara individual terhadap variabel terikat. 
Hasil uji homogenitas new environmental paradigm pada masyarakat pria dan wanita dengan kemampuan pengelolaan tata ruang permukiman bantaran sungai tinggi dan rendah menunjukan bilai $\chi^{2}$ hitung dengan uji Barlett sebesar 0,86 lebih kecil dari $\chi_{\text {tabel }}^{2}$ sebesar 7,815 dengan

Tabel 3. Uji homogenitas dengan metode Bartlett

\begin{tabular}{|l|l|l|l|l|l|}
\hline Sampel & $\mathrm{Dk}$ & $1 / \mathrm{dk}$ & $\mathrm{Si}^{2}$ & $\log \mathrm{S}^{2}$ & $(\mathrm{dk}) \log \mathrm{S}^{2}$ \\
\hline A1B1 & 18 & 0.0556 & 17.3158 & 1.2384 & 22.2920 \\
\hline A1B2 & 18 & 0.0556 & 15.8012 & 1.1987 & 21.5764 \\
\hline A2B1 & 18 & 0.0556 & 21.5906 & 1.3343 & 24.0168 \\
\hline A2B2 & 18 & 0.0556 & 23.0936 & 1.3635 & 24.5428 \\
\hline Jumlah & 72 & 0.2222 & 77.8012 & - & 92.4280 \\
\hline
\end{tabular}

Pengujian homogenitas menunjukan bahwa data-data tersebut dari populasi yang homogen. Dengan demikian persyaratan untuk analisis varian dua jalur terpenuhi, yakni data berdistribusi normal dan homogen.

Pengujian hipotesis penelitian dilakukan dengan analisis varians 2 jalur (ANAVA dua jalur) untuk hipotesis pertama, kedua dan kelima. Untuk hipotesis ketiga dan keempat dilakukan uji dua kelompok dengan menggunakan uji Tukey. Hasil perhitungan ANAVA dua jalur disajikan dalam tabel berikut: probabilitas 0,05 , sehingga dapat dismpulkan bahwa data new environmental paradigm pada masyarakat pria dan wanita dengan kemampuan pengelolaan tata ruang permukiman bantaran sungai tinggi dan rendah merupakan data yang homogen karena $\chi_{\text {hitung }}^{2}<\chi_{\text {tabel. }}^{2}$

Tabel 4.

Hasil perhitungan ANAVA 2 JALUR

\begin{tabular}{|c|c|c|c|c|c|c|}
\hline \multirow{2}{*}{$\begin{array}{l}\text { Sumber } \\
\text { Variansi }\end{array}$} & \multirow{2}{*}{$\mathrm{dk}$} & \multirow{2}{*}{ JK } & \multirow{2}{*}{ RJK } & \multirow{2}{*}{ F hitung } & \multicolumn{2}{|l|}{ F tabel } \\
\hline & & & & & $\square \square 0.05$ & $\square \square 0.01$ \\
\hline $\begin{array}{l}\text { Antar } \\
\text { kelompok }\end{array}$ & 3 & $\begin{array}{l}457.1 \\
05\end{array}$ & 152.368 & 6.029 & 2.732 & 4.066 \\
\hline $\begin{array}{l}\text { Dalam } \\
\text { kelompok }\end{array}$ & 72 & $\begin{array}{l}1,819 \\
.526\end{array}$ & 25.271 & & & \\
\hline Kolom (A) & 1 & $\begin{array}{l}229.2 \\
63\end{array}$ & 229.263 & 9.072 & & \\
\hline Baris (B) & 1 & $\begin{array}{l}121.2 \\
63\end{array}$ & 121.263 & 4.798 & 3.968 & 6.985 \\
\hline Interaksi & 1 & $\begin{array}{l}106.5 \\
79\end{array}$ & 106.579 & 4.217 & & \\
\hline Jumlah & 75 & $\begin{array}{l}1,857 \\
.53\end{array}$ & & & & \\
\hline
\end{tabular}

${ }^{\mathrm{ns}}=$ non Signifikan

* = Signifikan

** = Sangat Signifikan

Berdasarkan pemaparan data dan hasil pengujian hipotesis secara statistik dapat disimpulkan sebagai berikut :Hasil uji hipotesis pertama menunjukkan bahwa terdapat perbedaan yang signifikan pada new environmental paradigm yang dipengaruhi kemampuan pengelolaan 
tata ruang dengan mendapatkan hasil $F_{\text {hitung }}=42,407>F_{\text {tabel }}=4,06$ pada taraf signifikansi $\alpha=0,05$. kemampuan pengelolaan tata ruang permukiman bantaran sungai mempunyai Seseorang memiliki kemampuan dalam pengelolaan tata ruang permukiman bantaran sungai dengan melakukan kegiatan:

a) keterpaduan;

b) keserasian, keselarasan, dan keseimbangan; c) keberlanjutan; d) keberdayagunaan dan keberhasilgunaan; e) keterbukaan; f) kebersamaan dan kemitraan; g) pelindungan kepentingan umum; h) kepastian hukum dan keadilan; dan i) akuntabilitas. Oleh karena itu, seseorang yang memiliki kemampuan pengelolaan tata ruang permukiman bantaran sungai, ditunjukkan dengan kemampuan seseorang yang tetap atas tujuan yang hendak dicapainya.

Hasil uji hipotesis kedua, menunjukkan bahwa terdapat perbedaan yang signifikan pada new environmental paradigm yang dipengaruhi gender. Dalam hasil penelitian ini diketahui bahwa masyarakat dengan gender lakilaki memiliki new environmental paradigm yang lebih baik dibandingkan dengan gender perempuan. Laki-laki memiliki kemampuan lebih tinggi daripada perempuan. Hal ini disebabkan oleh peranan laki-laki sebagai kepala keluarga yang akan memberikan dominasi dalam kegiatan pngelolaan tata ruang permukiman bantaran sungai.

Hasil penelitian diperoleh ditemukan perbedaan signifikan new environmental paradigm pada kelompok masyarakat laki-laki yang memiliki kemampuan pengelolaan permukiman bantaran sungai tinggi dan kemampuan pengelolaan permukiman bantaran sungai rendah. Seperti yang telah dikemukakan di atas bahwa lakilaki cenderung lebih memperhatikan lingkungan dibandingkan perempuan, maka pengaruh kemampuan pengelolaan permukiman bantaran sungai sangat berpengaruh dalam mendorong new environmental paradigm. Dengan kata lain, laki-laki yang mempunyai new environmental paradigm tinggi lebih baik dibandingkan dengan yang memiliki new environmental paradigm rendah. Laki-laki mempunyai peran penting sebagai kepala rumah tangga dalam keluarga untuk menjaga dan melindungi keluarga, sehingga laki-laki berusaha mengambil langkah-langkah yang tepat untuk menjaga lingkungan di sekelilingnya. Jenis kelamin merupakan identitas secara biologis 
manusia dilahirkan terdiri dari jenis kelamin laki-laki atau perempuan. Jenis Kelamin adalah status yang dianggap seseorang berasal karena dilahirkan.

Hasil penelitian diperoleh ditemukan perbedaan signifikan new environmental paradigm pada kelompok masyarakat perempuan yang memiliki kemampuan pengelolaan tata ruang permukiman bantaran sungai tinggi dan kemampuan pengelolaan tata ruang permukiman bantaran sungai rendah. Hal ini karena gender pria dikonstruksikan secara sosial budaya untuk bersikap menjaga dan memelihara dalam keluarga, sehingga cenderung menjaga lingkungan untuk kepentingannya. Ditambah lagi, gender wanita dikonstruksikan bersifat feminim yang bertindak secara perasaan berdasarkan pengetahuan yang dimiliki, sehingga new environmental paradigm dipengaruhi oleh pengetahuan dari masing-masing individu. Oleh karena itu, kemampuan pengelolaan tata ruang permukiman bantaran sungai tidak berpengaruh signifikan terhadap new environmental paradigm pada gender wanita.

Berdasarkan penjelasan tersebut di atas, diduga terdapat perbedaan new environmental paradigm perempuan yang memiliki kemampuan pengelolaan tata ruang pemukiman bantaran sungai yang tinggi dengan yang rendah.

Uji hipotesis, ditemukan bahwa terdapat hubungan interaksi antara kemampuan pengelolaan tata ruang permukiman bantaran sungai dan gender terhadap new environmental paradigm pada analisis hipotesis ANAVA dua jalur.

Secara keseluruhan diketahui bahwa ditemukan perbedaan new environmental paradigm pada masyarakat dengan kemampuan pengelolaan tata ruang permukiman bantaran sungai tinggi dan kemampuan pengelolaan tata ruang permukiman bantaran sungai rendah. Ditambah lagi, diperkuat dengan adanya perbedaan new environmental paradigm pada gender laki-laki dan gender perempuan. Dengan demikian paradigma manusia yang terdiri dari gender laki-laki dan perempuan yang berkaitan dengan pola pikir dan tindakan yang berhubungan dengan lingkungan yang selalu terkait dengan antroposentris dan ecosentrism, antroposentris biasanya berkaitan dengan pola pikir dan tindakan yang anti lingkungan, sedangkan ecosentris merupakan pola pikir dan tindakan pro lingkungan. 


\section{KESIMPULAN}

Berdasarkan hasil pembahasan hasil penelitian, bahwa terdapat perbedaan new environmental paradigm antara masyarakat yang memiliki kemampuan pengelolaan tata ruang permukiman bantaran sungai tinggi dan kemampuan pengelolaan tata ruang permukiman bantaran sungai rendah. Terdapat perbedaan new environmental paradigm masyarakat bergender lakilaki maupun perempuan. Terdapat pengaruh interaksi yang signifikan antara kemampuan pengelolaan tata ruang permukiman bantaran sungai dan gender terhadap new environmental paradigm, dan terdapat interaksi antara kemampuan pengelolaan tata ruang permukiman bantaran sungai dan gender terhadap new environmental paradigm.

Hal ini dapat disimpulkan bahwa new environmental paradigm masyarakat dapat dipengaruhi melalui kemampuan pengelolaan tata ruang permukiman bantaran sungai dan gender. Namun demikian, jika new environmental paradigm ingin ditingkatkan, kemampuan pengelolaan tata ruang permukiman bantaran sungai dan gender dapat diambil dalam pertimbangan masing-masing.
Berdasarkan kesimpulan di atas, maka penelitian ini memberikan implikasi bahwa kemampuan pengelolaan tata ruang permukiman bantaran sungai (aktif dan efektif) pemerintah dapat mengarahkan dan mempengaruhi masyarakat yang akan berdampak baik melalui partisipasi dalam kegiatan pengelolaan lingkungan. Sehingga pemenuhan regulasi yang mendorong pengurang resiko lingkungan akan berdampak peningkatan perbaikan kualitas lingkungan dalam mendukung normalisasi sungai.

Kemampuan pengelolaan tata ruang pemukiman bantaran sungai adalah kapasitas individu untuk mewujudkan berbagai tugas dalam pekerjaan pengelolaan tata ruang pemukiman bantaran sungai yang diukur melalui Instrumen dari variabel yang di susun berdasarkan kisi-kisi dengan dimensi: a) keterpaduan; b) keserasian, keselarasan, dan keseimbangan; c) keberlanjutan; d) keberdayagunaan dan keberhasilgunaan; e) keterbukaan; f) kebersamaan dan kemitraan; g) pelindungan kepentingan umum; h) kepastian hukum dan keadilan; dan i) akuntabilitas.

Berdasarkan kesimpulan, implikasi penelitian di atas, maka dapat diberikan saran sebagai berikut: Bagi Institusi Pemerintah Provinsi DKI Jakarta. 
Untuk mencapai new environmental paradigm, diharapkan mengarahkan, memotivasi dan memperlihatkan perilaku kepada masyarakat yang dapat meningkatkan kepedulian lingkungan. Dibutuhkan kinerja dan komitmen dengan dimensi kemampuan bpengelolaan tata ruang permukiman bantaran sungai yang tinggi dari seluruh masyarakat sekitar bantaran sungai agar dalam menjalankan program mengembalikan fungsi sungai dalam rangka pembangunan berkelanjutan dapat dicapai.

Dengan penelitian ini, beberapa temuan penelitian belum memenuhi hipotesis penelitian, maka diharapkan melanjutkan penelitian ini dengan pengembangan butir instrumen dan penambahan jumlah sampel penelitian.

Peneitian ini merupakan awal untuk melihat konsep new environmental paradigm yang dilakukan pada masyarakat sekitar bantaran sungai, yang selama ini penelitian banyak mengaitkan konsep new environmental paradigm pada dunia pemerintahan.

\section{DAFTAR PUSTAKA}

Adisasmata, Rahardjo H. 2012. Analisis Tata Ruang Pembangunan. Yogyakarta: Graha Ilmu,
Ali, Muhidin Sambas. 2007. Analisis Korelasi, Regresi dan Jalur dalam Penelitian. Bandung: Pustaka Setia

American Psychological Association. 2011.Definition of Term : Sex, Gender Identity, Sexual Orientaion.

Arikunto, Suharsimi. Manajemen Penelitian. Jakarta: Rineka Cipta, 2005.

Barter, Nick and Jan Bebbington. Environmental Paradigms and Organisations with an Environmental Mission. International Journal of Innovation and Sustainable Development, 2012 Vol.6, No.2, pp. 120 - 145.

Best, John W. 1982. Research in Education. New Delhi: Prentice Hall of India Private Limited.

Burn, Shawn Meghan et.al.2012. Gender, Ethnic Identity, and Environmental Concern in Asian Americansand European Americans. Journal Research in Human Ecology.

Chayaripura, Ery.1997. "Makalah Manajemen Pembangunan Kota yang berwawasan lingkungan" dalam majalah Himpunan Karangan Ilmiah di bidang Perkotaan dan Lingkungan. Jakarta: KPPL Wilayah Jabodetabe.

Dirjen Penataan Ruang Departemen Permukiman dan Prasarana Wilayah, Pengembangan Wilayah dan Penataan Ruang di Indonesia, Tinjauan Teoritis Praktis, 2008. 
Ditjen Bangda Depdagri, Ruang Terbuka Hijau Kota (Inmendagri Nomor 14 Tahun 1988), Seminar Aktualisasi dan Pembinaan RTHK. Jakarta: Ditjen Bangda Depdagri, 1994.

Dunn, William N. 2000. Pengantar Analisis Kebijakan Publik, Edisi Kedua. Yogyakarta: Gadjah Mada University Press.

Dye, Thomas R. Understanding Public Policy, Elevent Edition. New Jersey: Pearson Printice Hall, 2005.

Hadi, Sudharto P. Penataan Ruang dan Lingkungan Hidup. Jendela Edisi13 Oktober, 2008.

Jhonson, Joy L., Robin Repta, Sex and Gender, Beyond the Binaries. USA: SAGE Publications, Inc., 2012.

Kannan, A. Rajamohan M.. Factors Influencing Organisational Climate In A Textile Mill. International Journal of Management and Social Science. 2014.

Kartono, Kartini. Pengantar Metodologi Riset Sosial. Bandung: Mandar Maju, 1996.

Kajian Akademis Undang-Undang Nomor 26 tahun 2007 Tentang Penataan Ruang (Jakarta: Fokus Media, 2007).

Kennedy, Emily Huddart et.al. Why We Don't "Walk the Talk": Understanding the Environmental Values/Behaviour, International Journal Human Ecology Review, Vol. 16, No. 2, 2009.
Kodoatie, Robert J. Rekayasa dan Manajemen Banjir Kota. Yogyakarta: ANDI 2013.

Kilbourne, William E. et.al. The role of the dominant social paradig minenvironment alattitudes $\mathrm{A}$ multinational examination. Journal Human EcologyReview, Vol. 16, No. 2. 2009.

. \& Michael J. Polonsky. Environmental Attitude sandtheir Relation to the Dominant Social Paradigm Among University Students In New Zealandand Australia. Australasian Marketing Journal 13 (2), 2005, h. 38.

Lester. James P. and Joseph Stewart, Jr. Public Polcy: An Evolutionary Approach. Belmont: Wadswort, 2000.

Lewis, Burt Rendal. Influence of the Dominant Social Paradigm on Consumer Environmental Attitudes, Valueand Behaviors, A Dissertation Submittedtothe Graduate Faculty of The University of Georgia, 2009, https://getd.libs.uga.edu/pdfs/le wis_burt_r_200905.23_phd.pdf ,(diakses 20 Mei 2014).

Linsey, Linda L.2011. The Sociology of Gender: Theoretical Perspectives and Feminist Frameworks. USA: Pearson Education.

Madu, B. C., \& Akobi, Thomas Ogbeche, A Path Analysis of Parental Socio-Economic status and Home Education Environment on Students' Academic Achievement in the 
Secondry Schools in Benue State, Nigeria. International Journal of Humanities and Social Science, 2014.

Maryati, Yatti. Intensitas Pencemaran Organik pada Daerah Aliran Sungai Ciliwung. Bogor: PPs IPB, 1999.

Moeleong, Lexy. J. Metodelogi Penelitian Kualitatif. Bandung: PT Remaja Rosdakarya, 2004.

Muliyono Sadyohutomo, Manajemen Kota dan Wilayah, Realita dan Tantangan (Jakarta: Bumi Aksara, 2008).

Notohadiprawiro, T. Tanah, Tataguna Lahan dan Tata Ruang dalam AMDAL. Yogyakarta: PPLHUGM, 1988.

Nugroho, Riant D. Public Policy. Jakarta: Penertbit Elex Media Kompetindo, Kelompok Gramedia, 2008.

, Kebijakan Publik, untuk Negara-Negara Berkembang, Jakarta: PT Elex Media Komputindo.

Oakley. Sex, Gender and Society. London: Temple Smith, 1972.

Parpart, Jane L. Patricia, \& Eudine Berriteau. Theoretical Perspectives on Gender and Development. Canada: National Library of Canada, 2000.

Perda No. 6 Tahun 1999 DKI Jakarta tentang RTRW Khusus Ibu Kota Jakarta. Jakarta: Pemda DKI,1999.
Poston, Dudley L. Jr., and Leon F. Bouvier. Population and Society: An Introduction to Demography. New York: Cambridge University Press, 2010.

Robbins, Stephen P. and Timoty A. Judge. Organisational Behavior. fifteenth edition. New Jersey: Prentice Hall, Inc,. 2012.

Rowland, David L. LucaIncrocci. Handbook of sexualand gender identity disorders. New Jersey: John Wiley \& Sons, 2008.

Salmah, Sjarifah. Penataan Bantaran Sungai Ditinjau dari Aspek Lingkungan. Jakarta: Trans Info Media, 2010.

Setyadi, Iwan Tritenty. 2005. Evaluasi Implementasi Proyek Inovasi Manajemen Perkotaan Pekerjaan Pemberdayaan Sektor Informal Pedagang Kaki Lima Kota Magelang. Tesis. Yogyakarta: MPKD Universitas Gadjah Mada.

Sekaran, Uma dan Roger Bougie. 2010. Research Methods for Business A Skill-Building Approach. New York: John Wiley \& Sons.

Sugandhy, Aca. 1999. Penataan Ruang dalam Pengelolaan Lingkungan Hidup. Jakarta: PT. Gramedia Pustaka Uatama.

Supriyatno, Budi. 2009. Manajemen Tata Ruang. Jakarta: CV. Media Brilian.

Sutanta, Hari. "Berita Bencana Alam dan Lingkungan, Alih Fungsi 
Lahan sebabkan Banjir di Jakarta”.

Undang-Undang Penataan Ruang No. 26 Tahun 2007. Jakarta: Sinar Grafika 2008.

UU No. 23 Tahun 1997 tentang Pengelolaan Lingkungan Hidup. Jakarta: Kementerian Negara LH, 1997.

UU No. 26 Tahun 2007 tentang Penataan Ruang. Jakarta: Departemen Pekerjaan Umum, 2007.

Usman, Husaini dan Purnomo Setiady Akbar, 2000. Metodologi Penelitian Sosial: Penelitian Evaluatif. Jakarta: PT. Bumi Aksara.

Viswewaran, Kamala. 2001. The

Common Destiny of Un/common Cultures. Durham: Vincenzo Romania, University Press.

Wibawa, Samodra., Yuyun Purbokusumo dan Agus Pramosinto. 1994. Evaluasi Kebijakan Publik. Jakarta: Raja Grafindo Persada. 